\title{
Effects of different mowing dates of plant top on tuber yield of Jerusalem artichoke (Helianthus tuberosus L.)
}

\author{
Ramazan Acar*, Rahim Ada and Abdullah Özköse \\ Selcuk University, Agriculture Faculty, Agronomy Department, Campus, 42003 Konya, Turkey. \\ Accepted 10 June, 2011
}

\begin{abstract}
This study was conducted to determine the effects of different mowing dates of plant top on tuber yield of Jerusalem artichoke (Helianthus tuberosus L) during 2005 and 2006 growing seasons. The experiment was designed according to the "split plots on randomized complete block" experimental design with three replications. Three different mowing dates [a: August 18 (before flowering), b: September 21 (beginning of flowering), c: October 20 (full flowering) and k: control (not-mowing)] and two varieties [red $(K)$ and white $(A)$ skin local Jerusalem artichoke] were taken as factors. Tuber yield and yield components were higher in the first mowing date and control than in the second and third mowing dates in 2005, 2006 and in the average of 2005 to 2006. Two years average maximum tuber yields per decare were $5149.78 \mathrm{~kg}$ in the control plots and $3327.27 \mathrm{~kg}$ in the plots of red skin of Jerusalem artichoke. The results suggest that first mowing date and control are suitable mowing times for tuber yield.
\end{abstract}

Key words: Jerusalem artichoke, mowing dates, tuber yield, dry matter yield.

\section{INTRODUCTION}

Jerusalem artichoke has been used for the purpose of human and animal nutrition, and also as a raw material for industrial or energy production. Jerusalem artichoke tubers are consumed by the people directly as fresh and it was also evaluated at many places as like potatoes tubers. Especially, the content in terms of care, is good for diabetes (Ilisulu, 1986). The effect of different planting dates on the yields of tuber and plant tops of Jerusalem artichoke were researched. Tuber yield were obtained with an average of $3808 \mathrm{~kg}$ (autumn sowing) and $2600 \mathrm{~kg}$ (15 April) per decare (Arslan, 1985). Plant and tuber characteristics of red and white skin local Jerusalem artichoke genotypes were determined in 2004. In the study, tuber number per plant, average tuber weight, tuber yield per plant and per hectare of red and white skin local Jerusalem artichoke genotypes were obtained as 47.67 number/plant, $29.55 \mathrm{~g}, 1.01 \mathrm{~kg} /$ plant, $28.80 \mathrm{t} /$ hectare and 47.67 number/plant, $25.95 \mathrm{~g}$ tuber, $1.23 \mathrm{~kg} /$ plant, and $35.03 \mathrm{t} /$ hectare respectively (Killi et al., 2005). Morphological traits and tuber yields of Jerusalem

${ }^{\star}$ Corresponding author. E-mail: racar@selcuk.edu.tr. Tel: +90 332 2232854. Fax: +90 3322410108. artichoke genotypes collected from different regions in Turkey were investigated. In this research, tuber number per plant, average tuber weight, tuber yield per plant, tuber yield per hectare and dry matter ratio of tuber were ranged between 16.6 to 34.4 number/plant, 37.3 to $49.9 \mathrm{~g}$ tuber, 651.7 to $1436.0 \mathrm{~g} /$ plant, 18.62 to $41.03 \mathrm{t} /$ hectare and 19.0 to $19.9 \%$, respectively (Çalişkan et al., 2003). Jerusalem artichoke tubers are white, red or purple skinned and ranging in size from 7.5 to $10 \mathrm{~cm}$ long and 3 to $5 \mathrm{~cm}$ thick. The first frost kills the stems and leaves, but tubers withstand freezing for months. Average tuber yields of 16 to 20 ton/ha may be expected from crops grown under ordinary farm conditions. Yields of tops for forage average are 18 to 28 ton/ha green weight (Duke, 1983). The effect of cutting of Helianthus tuberosus stands has been studied by the comparison of both mown (2 to 4 times) and not mown populations during four years. The repeated mowing reduced the number and viability of ramets (during the growing season the decrease of shoots on not-mown plots was not as rapid as on mown plots). On mown plots, there was a higher initiate density in spring in comparison with the not mown populations (the higher number of shoots could be induced by the stress generated by cutting during the previous year). During research, no generative organs 


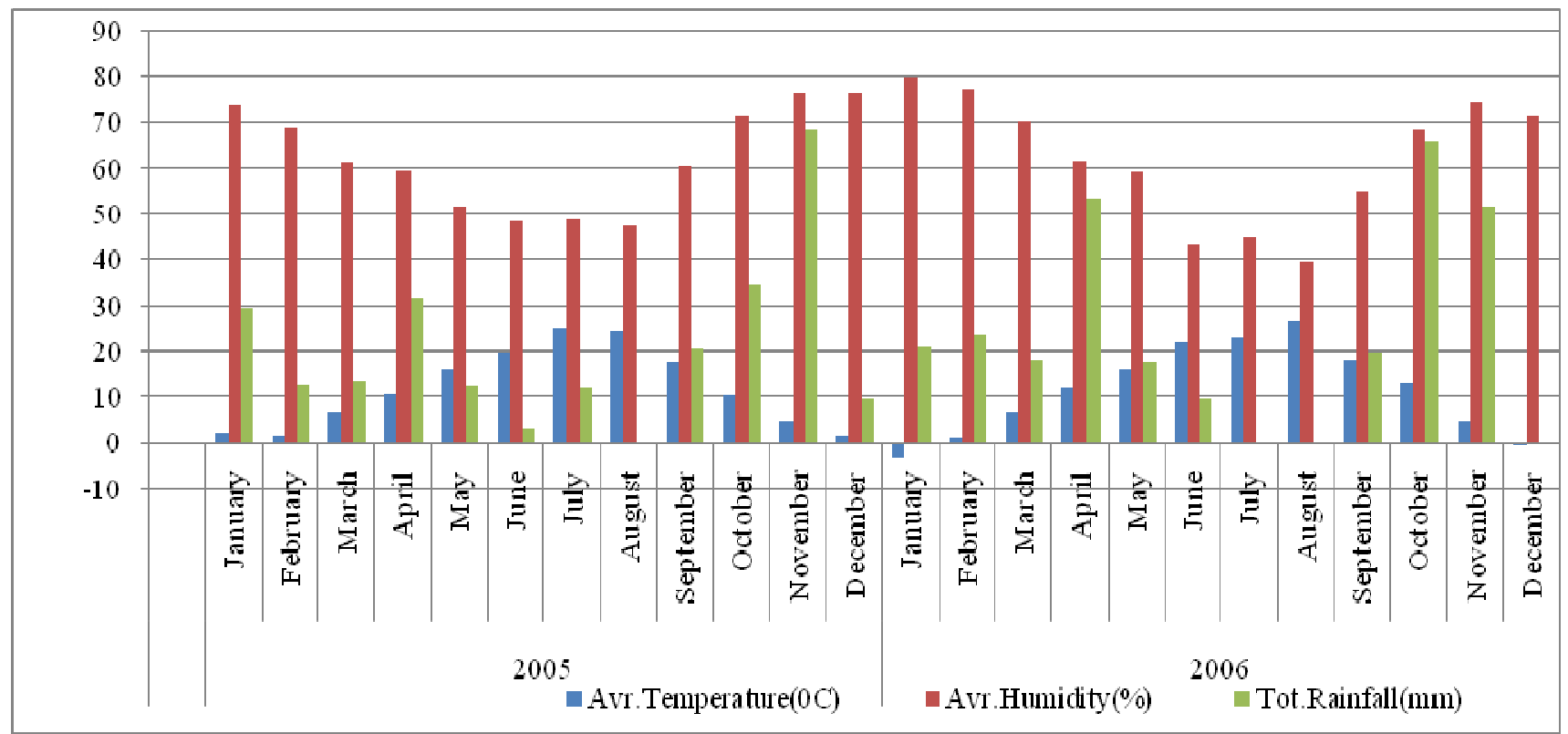

Figure 1. Monthly temperature, humidity and rainfall of Konya region.

Have been observed on mown plants (Feher and Koncekova, 2009). Jerusalem artichoke has excellent potential as a carbohydrate-rich crop. The growth of plant tops and tubers are influenced by the flowering process. Tubers develop from the stolons which enlarge with the onset of flowering. The number of tubers increased until percent flowering occurred and subsequently declined to approximately 25 tubers/plant. During that time, the weight per tuber increased exponentially. It is hypothesized that translocation of material from some tubers, as well as leaf senescence, contributes to increasing the rate of individual tuber dry matter accumulation. Tuber yields were $283.5 \mathrm{~g} \mathrm{DM} /$ plant, which is equivalent to 9450 $\mathrm{kg} \mathrm{DM} / \mathrm{ha}$ (42 $\mathrm{t} / \mathrm{ha}$ fresh weight). Plant growth was terminated by killing frosts (Stauffer at al., 2010). In the study, tuber yields of Jerusalem artichoke which were mowed at the top of plant were determined.

\section{MATERIALS AND METHODS}

This research was conducted to determine the effects of different mowing dates of plant top on tuber yield of Jerusalem artichoke $(H$. tuberosus L) during 2005 and 2006 growing seasons. The experiment was designed according to the "split plots on randomized complete block" with three replications. Three different mowing dates [a: August 18 (before flowering), b: September 21 (beginning of flowering), c: October 20 (full flowering) and k: control (not-mowing)] and two varieties [red $(\mathrm{K})$ and white $(\mathrm{A})$ ] of skin local Jerusalem artichoke were taken as factors. Planting date was April 5th to 6th. Plants were 7 to $9 \mathrm{~cm}$ deep, in row of $50 \mathrm{~cm}$ wide with 30 $\mathrm{cm}$ between plants. Each plot area was $11.25 \mathrm{~m}^{2}(2.5 \mathrm{~m} \times 4.5 \mathrm{~m}) . \mathrm{N}$ was applied at the rate of $70 \mathrm{~kg} \mathrm{ha}^{-1}$ and $\mathrm{P}_{2} \mathrm{O}_{5}$ at $130 \mathrm{~kg} \mathrm{ha}^{-1}$. Jerusalem artichoke was irrigated 7 to 8 times until the harvesting date. Harvesting date was November 18 after frost (Gençkan, 1983). The climate of the research area is shown in Figure 1.
Climate of the region can be defined as semi-arid continental. The summers were dry and had warm day-temperatures. During the growing season, rainfall was not enough for Jerusalem artichoke. Average altitude of the research area was $1050 \mathrm{~m}$. Characters of the study area were clay loam soil within the area which had a trial $(0$ to $60 \mathrm{~cm}$ ), level of the medium organic matter ratio $(2.31 \%)$ and slightly alkaline $\mathrm{pH}(\mathrm{pH} 8.00)$. There was no soil salinity problem with high lime content $(36.00 \%)$ of the soil. All samples were dried at $70^{\circ} \mathrm{C}$ for $48 \mathrm{~h}$ and weighed for dry matter ratio and yield. Analysis of variance was done by using a MSTAT-C statistic programmed and differences were compared by LSD tests.

In this research, tuber number per plant, average tuber weight, tuber yield per plant, tuber yield per decare (metric unit equal 1000 $\mathrm{m}^{2}$ ), dry matter ratio of tuber and dry matter yield per decare were determined.

\section{RESULTS AND DISCUSSION}

The effects of different mowing dates of plant top on tuber yield of Jerusalem artichoke were investigated in 2005 and 2006. The results of this research are shown in Table 2. The effects of different mowing dates of plant top on tuber number per plant, average tuber weight, tuber yield per plant, tuber yield per decare and dry matter yield per decare were found significant. The effect of varieties was not statistically significant (Table 1). Tuber yield and yield components were obtained from the first mowing date. The control was higher than that of the second and third mowing dates in 2005, 2006 and the average of 2005 to 2006. Tuber yield and yield components decreased in the second and third mowing dates in 2005, 2006 and in the average of 2005 to 2006 (Table 2). Maximum tuber yield per plant and per decare in 2005 were taken from the first mowing date $(568.33 \mathrm{~g}$ and 
Table 1. Variance analysis results of this research.

\begin{tabular}{llcc}
\hline Parameter & Factor & $\mathbf{2 0 0 5}$ & $\mathbf{2 0 0 6}$ \\
\hline \multirow{3}{*}{ Tuber number per plant } & Varieties & 0.6124 & 1.1951 \\
& Mowing dates & $4.2751^{\star}$ & $10.6997^{\star *}$ \\
& Interaction & 0.9896 & 0.5687 \\
& Varieties & & \\
Tuber yield per plant $(\mathrm{g})$ & Mowing dates & 0.1488 & 0.0586 \\
& Interaction & 1.7258 & 1.5626 \\
& & & \\
& Varieties & 0.9410 & 0.0085 \\
Average tuber weight $(\mathrm{g})$ & Mowing dates & $6.8608^{\star *}$ & $5.8644^{\star *}$ \\
& Interaction & 0.9831 & 1.4544 \\
& & & \\
& Varieties & 0.1470 & 1.3558 \\
Tuber yield per decare $(\mathrm{kg})$ & Mowing dates & $9.2028^{\star *}$ & $58.1576^{* *}$ \\
& Interaction & 1.7273 & 0.2487 \\
& & & \\
& Varieties & 0.7817 & 0.0879 \\
Dry matter ratio of tuber $(\%)$ & Mowing dates & 0.2864 & 0.7893 \\
& Interaction & 0.3137 & 0.7621 \\
& & & \\
& Varieties & 0.9758 & 0.0373 \\
Dry matter yield per decare $(\mathrm{kg})$ & Mowing dates & $4.4834^{\star *}$ & $18.6896^{* *}$ \\
& Interaction & 1.5257 & 0.3300 \\
\hline
\end{tabular}

${ }^{*} \mathrm{P}<0.05 ;{ }^{* *} \mathrm{P}<0.01$.

$3789.55 \mathrm{~kg}$, respectively) and the control (642.83 $\mathrm{g}$ and $4285.68 \mathrm{~kg}$, respectively). Maximum tuber yield per plant and per decare in 2006 were also taken from the first mowing date (649.83 g and $6336.87 \mathrm{~kg}$, respectively) and the control (781.17 $\mathrm{g}$ and $6013.88 \mathrm{~kg}$, respectively) (Table 2). Two year average maximum tuber yields per decare was $5149.78 \mathrm{~kg}$ in the control plots and 3327.27 $\mathrm{kg}$ in the plots of red skin of Jerusalem artichoke. Minimum tuber yield per plant and per decare were obtained from the second mowing date in the average of 2005 to 2006. Harvesting (control) was made in all the plots at the same time; during November, 18 after frost.

Mowing of plant top solely affects the development of tuber of Jerusalem artichoke (Feher and Koncekova, 2009). It prompted tuber or top of plant to be taken as animal feed, and can be harvested between June and October. If both tuber and top of the plant is to be harvested, top of the plant should be mowed until the end of June. In this case, because of delayed harvest, tuber yield is reduced. If it were harvested in June, development of tuber would be complete before the beginning of fall and winter (Gençkan, 1983). Stauffer et al. (2010) stated that tuber yield and growing of Jerusalem artichoke is done at different flowering times because of transport of organic materials in these times. The factors affecting photosynthesis are the environment and plant aptitude. One of the plant factors is leaf area index (Kacar, 1989; Gökkuş, 2009). Photosynthesis products which produced in the green parts of plant are moved to each sides of plant for growth, development and storage. The distribution of photosynthesis products and inorganic nutrients between organs is affected by the rate of dry matter and the production efficiency of harvested plant. This is the time when new leaves are provided with nutrients from other plant parts (Çelik, 1998). Substances reserved in roots of plant should be spent for the formation of the green parts (shoots and leaves) of grazing and mowing plants. Grazing and mowing is done to often reduced storage of nutrients (Altin et al., 2011). The effect of different mowing dates of plant top on tuber yield of Jerusalem artichoke $(H$. tuberosus $L)$ is important in terms of the movement of photosynthesis products in different growing times.

\section{Conclusion}

There are many advantages of Jerusalem artichoke in terms of their usage in agriculture. Jerusalem artichoke is capable of adapting to any condition, and can grow in many parts of the world and almost in any sort of soil conditions. Jerusalem artichoke is not selective in terms 
Table 2. Effects of different mowing dates of plant top and varieties on tuber yield and yield components and LSD.

\begin{tabular}{|c|c|c|c|c|c|c|c|c|c|c|c|c|c|c|c|c|c|}
\hline \multirow{3}{*}{\multicolumn{2}{|c|}{ Parameter }} & \multirow{3}{*}{ Variety } & \multicolumn{15}{|c|}{ Mowing time } \\
\hline & & & \multicolumn{5}{|c|}{2005} & \multicolumn{5}{|c|}{2006} & \multicolumn{5}{|c|}{ Average (2005-2006) } \\
\hline & & & $\mathbf{a}$ & b & c & $\mathbf{k}$ & Ave. & a & b & c & $\mathbf{k}$ & Ave. & $\mathbf{a}$ & b & c & k & Ave. \\
\hline \multicolumn{2}{|c|}{ Tuber number per plant } & A & 16.30 & 6.68 & 7.80 & 11.17 & 10.48 & 10.40 & 4.70 & 4.37 & 15.40 & 8.72 & 13.35 & 5.69 & 6.09 & 13.29 & 9.60 \\
\hline \multirow[t]{2}{*}{ LSD } & 5.4091 * & $\mathrm{K}$ & 14.73 & 6.13 & 14.33 & 12.40 & 11.90 & 15.77 & 6.88 & 3.07 & 17.07 & 10.70 & 15.25 & 6.51 & 8.70 & 14.74 & 11.30 \\
\hline & $4.5092^{* *}$ & Ort. & $15.51^{\mathrm{a}}$ & $6.40^{\mathrm{b}}$ & $11.07^{\mathrm{ab}}$ & $11.78^{\mathrm{ab}}$ & 11.19 & $13.08^{\mathrm{a}}$ & $5.79^{b}$ & $3.72^{b}$ & $16.23^{\mathrm{a}}$ & 9.71 & 14.30 & 6.10 & 7.40 & 14.00 & 10.45 \\
\hline \multicolumn{2}{|c|}{ Tuber yield (g/plant) } & $A$ & 612.67 & 159.67 & 246.33 & 762.00 & 445.18 & 541.00 & 130.33 & 157.00 & 881.00 & 427.33 & 576.84 & 145.00 & 201.67 & 821.50 & 436.26 \\
\hline \multirow[t]{2}{*}{ LSD } & 302.01 ** & $\mathrm{K}$ & 524.00 & 164.00 & 458.33 & 523.67 & 417.50 & 758.67 & 193.17 & 143.33 & 681.33 & 444.12 & 641.34 & 178.59 & 300.83 & 602.50 & 430.81 \\
\hline & $173.82^{* *}$ & Ort. & $568.33^{\mathrm{a}}$ & $161.83^{\mathrm{b}}$ & $352.33^{\mathrm{ab}}$ & $642.83^{\mathrm{a}}$ & 431.34 & $649.83^{\mathrm{a}}$ & $161.75^{\mathrm{b}}$ & $150.17^{b}$ & $781.17^{\mathrm{a}}$ & 435.73 & 609.08 & 161.79 & 251.50 & 712.00 & 433.54 \\
\hline \multicolumn{2}{|c|}{ Avr. tuber weight (g) } & A & 41.46 & 24.97 & 27.44 & 68.31 & 40.55 & 47.44 & 30.11 & 34.91 & 54.63 & 41.77 & 44.45 & 27.54 & 31.18 & 61.47 & 41.16 \\
\hline \multirow[t]{2}{*}{ LSD } & $23.241^{* *}$ & $\mathrm{~K}$ & 35.02 & 26.93 & 30.92 & 47.90 & 35.19 & 48.88 & 28.07 & 47.15 & 44.41 & 42.13 & 41.95 & 27.50 & 39.04 & 46.16 & 38.66 \\
\hline & $9.6142^{* *}$ & Ort. & $38.24^{\mathrm{ab}}$ & $25.95^{\mathrm{b}}$ & $29.18^{b}$ & $58.11^{\mathrm{a}}$ & 37.87 & $48.16^{\mathrm{a}}$ & $29.09^{b}$ & $41.43^{\mathrm{a}}$ & $49.52^{\mathrm{a}}$ & 41.95 & 43.20 & 27.52 & 35.11 & 53.82 & 39.91 \\
\hline \multicolumn{2}{|c|}{ Tuber yield (kg/da) } & A & 4084.00 & 1067.57 & 1643.57 & 5080.23 & 2968.84 & 5979.30 & 944.47 & 958.37 & 5805.53 & 3421.92 & 5031.65 & 1006.02 & 1300.97 & 5442.88 & 3195.38 \\
\hline \multirow[t]{2}{*}{ LSD } & $20.131^{* *}$ & $\mathrm{~K}$ & 3495.10 & 1096.87 & 3058.70 & 3491.13 & 2785.45 & 6694.43 & 1684.70 & 874.97 & 6222.23 & 3869.08 & 5094.77 & 1390.79 & 1966.84 & 4856.68 & 3327.27 \\
\hline & $956.62^{* *}$ & Ort. & $3789.55^{\mathrm{a}}$ & $1082.22^{b}$ & $2351.13^{\mathrm{ab}}$ & $4285.68^{a}$ & 2877.15 & $6336.87^{\mathrm{a}}$ & $1314.58^{b}$ & $916.67^{b}$ & $6013.88^{\mathrm{a}}$ & 3645.50 & 5063.21 & 1198.40 & 1633.90 & 5149.78 & 3261.33 \\
\hline \multicolumn{2}{|c|}{ Dry matter ratio (\%) } & A & 17.50 & 18.13 & 18.53 & 22.54 & 19.17 & 27.85 & 28.44 & 28.77 & 28.71 & 28.44 & 22.68 & 23.29 & 23.65 & 25.63 & 23.81 \\
\hline \multicolumn{2}{|l|}{ LSD } & K & 17.97 & 17.29 & 16.45 & 17.35 & 17.27 & 29.12 & 28.55 & 32.99 & 25.27 & 28.98 & 23.55 & 22.92 & 24.72 & 21.31 & 23.13 \\
\hline & & Ort. & 17.74 & 17.71 & 17.49 & 19.94 & 18.22 & 28.48 & 28.49 & 30.88 & 26.98 & 28.71 & 23.11 & 23.10 & 24.19 & 23.46 & 23.47 \\
\hline \multicolumn{2}{|c|}{ Dry matter yield $(\mathrm{kg} / \mathrm{da})$} & A & 712.39 & 196.95 & 301.95 & 1235.70 & 611.75 & 1451.91 & 268.27 & 274.74 & 1655.75 & 912.67 & 1082.15 & 232.61 & 288.35 & 1445.73 & 762.21 \\
\hline \multirow[t]{2}{*}{ LSD } & $364.91^{* *}$ & $\mathrm{~K}$ & 584.73 & 190.85 & 504.43 & 588.17 & 467.05 & 1214.09 & 458.69 & 286.67 & 1570.62 & 882.52 & 899.41 & 324.77 & 395.55 & 1079.40 & 674.79 \\
\hline & 389.02 ** & Ort. & $648.56^{\mathrm{ab}}$ & $193.90^{c}$ & $403.19^{b c}$ & $911.93^{\mathrm{a}}$ & 539.40 & $1332.99^{a}$ & $363.48^{\mathrm{b}}$ & $280.71^{b}$ & $1613.18^{\mathrm{a}}$ & 897.60 & 990.78 & 278.69 & 341.95 & 1262.55 & 718.50 \\
\hline
\end{tabular}

(1) 2005; (2) 2006;* $<<0.05$; ${ }^{*} \mathrm{P}<0.01$ ) white $(\mathrm{A})$ and red $(\mathrm{K})$ skin of Jerusalem artichoke; a: 1 , mowing time b: 2 , mowing time c: 3 , mowing time $\mathrm{k}$ : control (harvesting time).

of environmental conditions, but can grow in various soil types and gives good results. Jerusalem artichoke tubers have resistance to sub-zero temperatures, so it grows in cold and hot seasons as well as in the moderate cold regions. It prefers humid and rainy climate. However, it necessitates watering in arid areas during summer. Jerusalem artichoke is also known as water-like plant. This plant has been used for the purpose of human and animal nutrition, as well as a raw material for energy production. For these reasons, Jerusalem artichoke should be supported for cultivation in suitable area where adequate rainfall or irrigation conditions are present. In order to obtain adequate yield, both top of plant and tuber and the times of mowing should be considered. According to overall findings obtained in this research, first mowing date and control are suitable mowing times for an adequate tuber yield. Varietals differences were statistically insignificant.

\section{REFERENCES}

Altın M, Gökkuş A, Koç A (2011). Range Management C1 T.C. Min. Agric. Rural Affairs. p. 468.

Arslan N (1985). Eınfluss von pflanzzeit auf den knollenertrag 
und grünnmasse von Helianthus tuberosus L. (Topinambur). J. Natural Sci. 9(2): 183-187.

Çalışkan ME, Çalışkan S, Arıoğlu H (2003). Morphological traits and tuber yields of Jerusalem artichoke (Helianthus tuberosus L) genotypes collected from different regions in Turkey under Hatay ecological conditions. 5. Crop Science Congress, Turkey, pp. 261265.

Çelik N (1998). Crop Physiology. Uludağ Univ. Agric. Fac. Publication, 79: p. 223.

Duke JA (1983). Helianthus tuberosus L. Handbook of Energy Crops (unpublished). www.hort.purdue.edu.

Feher A, Koncekova $L$ (2009). Evaluation of mechanical regulation of invasive Helianthus tuberosus populations in agricultural landscape. J. Central Eur. Agric. 10(3): 245-250.

Gençkan MS (1983). Forage Plants. Ege Univ. Agric. Fac. Publication, 467: p. 519.
Gökkuş A (2009). Ecology and physiology of forage plants. In: Avcıoğlu R, Hatipoğlu R, Karadağ Y (Eds.). Forage Plants Book C1. T.C. Min. Agric. Rural Affairs, pp. 65-93.

İlisulu K (1986). Starch and Sugar Crops. Ankara Univ. Agric. Fac. Publication, 960: p. 278.

Kacar B (1989). Plant Physiology. Ankara Univ. Agric. Fac. Publication 1153: p. 424

Kıllı F, Şerefoğlu AH, Şaştı H (2005). Plant and tuber characteristics of red and white skin local Jerusalem artichoke (Helianthus tuberosus L.) genotypes. 6. Crop Sci. Congress, Turk. pp. 1137-1140.

Stauffer MD, Chubey BB, Dorell DG (2010). Growth, yield and compositional characteristics of Jerusalem artichoke as it relates to biomass production. www.anl.gov/PCS/acsfuel. 